\title{
Isolation of Cell-Free miRNA from Biological Fluids: Influencing Factors and Methods
}

\author{
Olga Bryzgunova ${ }^{1,2, *(\mathbb{D})}$, Maria Konoshenko ${ }^{1,2}$, Ivan Zaporozhchenko ${ }^{3}$, Alexey Yakovlev ${ }^{1,2}$ (D) \\ and Pavel Laktionov 1,2 \\ 1 Institute of Chemical Biology and Fundamental Medicine, Siberian Branch, Russian Academy of Sciences, \\ 630090 Novosibirsk, Russia; msol@ngs.ru (M.K.); 05alex98@mail.ru (A.Y.); lakt@niboch.nsc.ru (P.L.) \\ 2 Meshalkin Siberian Federal Biomedical Research Center, Ministry of Public Health of the Russian Federation, \\ 630055 Novosibirsk, Russia \\ 3 Department of Molecular Biology and Genetics, Aarhus University, 8000 Aarhus, Denmark; \\ ivanzap@niboch.nsc.ru \\ * Correspondence: olga.bryzgunova@niboch.nsc.ru; Tel.: +383-363-5144
}

Citation: Bryzgunova, O.;

Konoshenko, M.; Zaporozhchenko, I.;

Yakovlev, A.; Laktionov, P. Isolation of Cell-Free miRNA from Biological

Fluids: Influencing Factors and

Methods. Diagnostics 2021, 11, 865.

https://doi.org/10.3390/

diagnostics 11050865

Academic Editor: Anastasia Malek

Received: 31 March 2021

Accepted: 4 May 2021

Published: 11 May 2021

Publisher's Note: MDPI stays neutral with regard to jurisdictional claims in published maps and institutional affiliations.

Copyright: (C) 2021 by the authors. Licensee MDPI, Basel, Switzerland. This article is an open access article distributed under the terms and conditions of the Creative Commons Attribution (CC BY) license (https:/ / creativecommons.org/licenses/by/ $4.0 /)$.

\begin{abstract}
A vast wealth of recent research has seen attempts of using microRNA (miRNA) found in biological fluids in clinical research and medicine. One of the reasons behind this trend is the apparent their high stability of cell-free miRNA conferred by small size and packaging in supramolecular complexes. However, researchers in both basic and clinical settings often face the problem of selecting adequate methods to extract appropriate quality miRNA preparations for use in specific downstream analysis pipelines. This review outlines the variety of different methods of miRNA isolation from biofluids and examines the key determinants of their efficiency, including, but not limited to, the structural properties of miRNA and factors defining their stability in the extracellular environment.
\end{abstract}

Keywords: extracellular vesicles; lipoproteins; binding to blood cells; cell-free miRNA structure; miRNA storage; isolation kit; miRNA isolation

\section{Introduction}

The biology of miRNA and their transport from cells and into intracellular space, including biological fluids, were actively studied in the last two decades. High stability and value of cell-free miRNA (cf-miRNA) suggests them as promising diagnostic and prognostic biomarkers for a plethora of diseases, including cancers of different origin [1-3].

Accurate evaluation of cf-miRNA profiles includes purification, quantification and intelligent data analysis (Figure 1).

The main features and efficacy of isolation techniques are hugely determined by the biological properties of miRNAs, their interaction with other biomolecules and packaging. In turn, purity and quality of retrieved cf-miRNA affect accuracy, reproducibility and reliability of their quantification.

miRNAs are small non-coding RNA molecules (19-22 nt) which can be vastly different in GC-content, base and backbone modifications (Table 1).

Small amount of miRNA is detected in the extracellular space and in biological fluids (see Figure 1 in [4]). Cf-miRNA stability in blood and other biofluids can be attributed to the protection from RNAses conferred by interaction with biomolecules as well as packaging in membrane-coated or membrane-free particles (Table 2).

These complexes strongly interfere with the isolation efficacy requiring liberation of miRNA from such structures to ensure effective cf-miRNA isolation and prevent coisolation of polymerase reaction inhibitors.

The key to successful study of cf-miRNAs by high throughput methods or precision techniques in research or clinical environment is the quantitative isolation of miRNAs 
from samples of biological fluids independent from their primary structure, modifications and content of biological fluids. Meanwhile, methodological aspects defining the efficacy and reproducibility of cf-miRNA purification and sample preparation often attract little attention, but in many real-life cases, diagnostically relevant margin of difference is rather narrow and, thus, accurate and reproducible pre-analytical approaches can significantly improve comparative analysis of miRNA expression. In this review, we provide an analysis of current methods of cf-miRNA purification from biological fluids and examine factors that affect its efficacy, including intrinsic features of miRNAs, packaging and common contaminants of miRNA preparations.

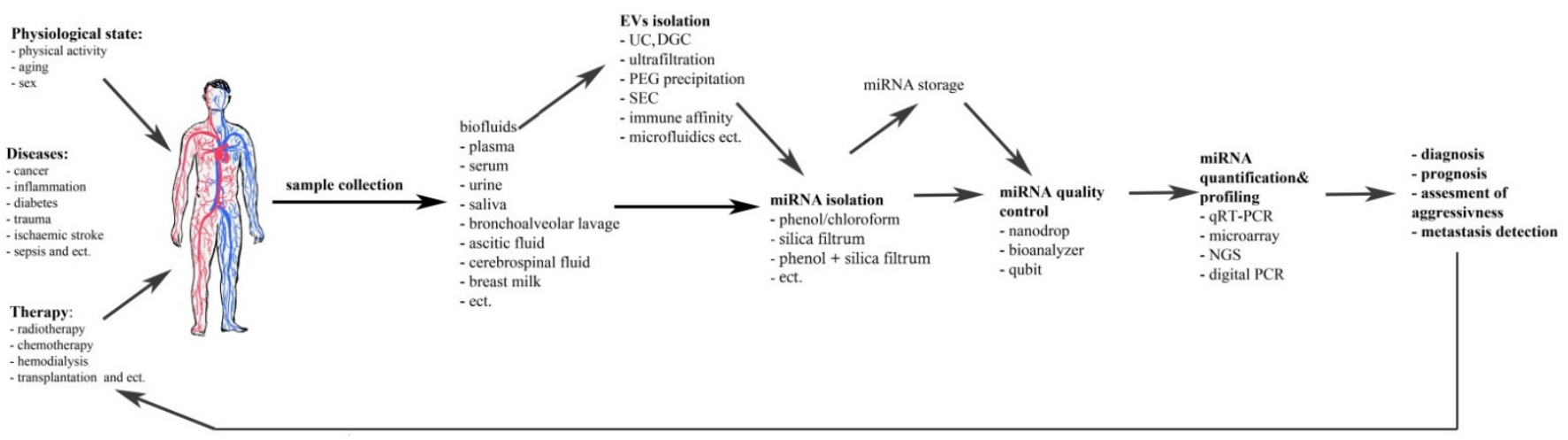

Figure 1. The scheme of cell-free miRNA investigations and their possible implementation.

Table 1. Features of the structure of cell-free miRNAs (possible variants of chemical modification).

\begin{tabular}{|c|c|}
\hline Chemical Modifications & Reference \\
\hline $3^{\prime}$-uridylation & {$[5-7]$} \\
\hline adenylation & {$[5,7]$} \\
\hline N6-methyladenosine (m6A) modification & [8-10] \\
\hline $3^{\prime}$-terminal 2'-O-methylation & {$[5,8,11,12]$} \\
\hline 5-methylcytosine (m5C) modification & {$[8,13]$} \\
\hline adenosine-to-inosine editing & {$[5-7,9,14]$} \\
\hline pseudouridine $(\Psi)$ modification & [8] \\
\hline
\end{tabular}

Table 2. Forms of cell-free miRNAs.

\begin{tabular}{lc}
\hline \multicolumn{1}{c}{ Forms of Binding } & References \\
\hline Membrane-coated microparticles & \\
Apoptotic bodies $(0.1-5 \mu \mathrm{m})$ & {$[15-17]$} \\
Microvesicles $(>0.5 \mu \mathrm{m})$ & {$[17-23]$} \\
Ectosomes $(100-600 \mathrm{~nm})$ & {$[24]$} \\
Oncosomes $(1-10 \mu \mathrm{m})$ & {$[17,25,26]$} \\
Exosomes $(30-150 \mathrm{~nm})$ & {$[17,18,22,24,27-33]$} \\
Specific microvesicles (prostasomes $(50 \mathrm{~nm}-0.5 \mu \mathrm{m})$, melanosomes & {$[33-37]$} \\
$(>0.5 \mu \mathrm{m})$, 'platelet dust' $(\sim 130-500 \mathrm{~nm}))$ & \\
\hline Membrane-free microparticles & {$[23,38-42]$} \\
High-density lipoproteins (HDL) & {$[39,40,42]$} \\
Low-density lipoproteins (LDL) & {$[23,43-49]$} \\
Various RNA-binding proteins (for example, AGO1, AGO2, \\
nucleophosmin $1(\mathrm{NPM})$, Tamm-Horsfall protein $(\mathrm{THP})$, etc.) & {$[50,51]$} \\
Exomeres $(\sim 35$ nm $(<50$ nm) $)$ & {$[27,32]$} \\
\hline miRNAs associated with the surface of blood cells & \\
\hline
\end{tabular}




\section{Overview of cf-miRNA Properties and Factors Influencing Their Extraction from Biofluids}

Depending on the cell type it can contain up to 120,000 total mature miRNA molecules [52] This molecular population is heterogeneous, with each miRNA containing (sometimes multiple) miRNA isoforms (isomiRs), different in the sequence of $5^{\prime}$ - or $3^{\prime}$-ends [53-55]. Additionally, immature miRNA species that may be present in the sample and should be excluded from quantification or analysis. Like other RNA species miRNA can carry a repertoire of base and backbone modifications, including methylation, uridinylation, adenylation, adenosine-to-inosine editing by RNA-dependent adenosine deaminase (ADAR) or inclusion of pseudouridines (Table 1) [5-7,11,56-60]. These modifications can additionally affect the half-life of specific miRNAs in biofluids by giving them increased resistance to exonucleases and higher affinity to miRNA binding biomolecules. For example, methylated miR-21-5p is more resistant to digestion by $3^{\prime} \rightarrow 5^{\prime}$ exoribonuclease polyribonucleotide nucleotidyltransferase 1 (PNPT1) and has higher affinity to Argonaute-2 (AGO2), which may contribute to its higher stability and stronger inhibition of programmed cell death protein 4 (PDCD4) translation, respectively [12]. Since cf-miRNAs originate from the cellular pool one can suppose that they also share the same structural features as cellular miRNA.

The lifetime of free RNAs in biological fluids is very short (15 s in blood according to [61]). This is due to the intrinsic lability of RNA structure, especially in the presence of bivalent metal cations, $[62,63]$ and due to high levels of ribonuclease and phosphodiesterase activity found in most biofluids [64-69]. Sequences with lower GC content and stable secondary duplex structures appear to be less stable and therefore at risk of being lost during the extraction process [70]. Despite this, endogenous RNA was shown to survive in bloodstream significantly longer-from several minutes to several hours or even days [71]. Cell-free miRNAs are relatively stable in blood, urine, cerebrospinal liquid, bronchoalveolar lavage, lymph, saliva, milk, tears and others resisting degradation at room temperature for up to 4 days and could withstand as boiling, multiple freeze-thaw cycles, high or low $\mathrm{pH}$ [72-74]. The observed stability is provided by complexing with proteins, lipoproteins, supramolecular complexes and packaging in membrane-coated vesicles and membranefree particles (Table 2).

Particle-free miRNAs are frequently found in complexes with proteins: such miRNAs like miR-16 and miR-92a, are mainly (up to 95\%) co-precipitated with the protein fraction [44]. In the cell, the main partners of miRNA are the Argonaute proteins (AGO1-4 in humans). It is therefore not surprising that cf-miRNA in supernatants of MCF-7 cells, blood [43], urine [75] and pericardial fluid [76] were found in strong complexes with AGO2 (Kd 20-80 nM) [77-79]. qRT-PCR profiling of 375 miRNAs in size-exclusion chromatography fractions of human plasma more than $67 \%$ of the assayed miRNAs were associated with fractions containing $\mathrm{AGO} 2$ protein and a corresponding portion of plasma miRNAs could be recovered by AGO2 immunoprecipitation from plasma [47]. In addition to AGO2, miRNA in blood can be in a complex with AGO1 [45].

In blood cf-miRNAs were also found in small complexes 30-40 kDa containing nucleophosmin (NPM1) [46] passing dialisis membranes, although this interaction found in vitro is yet to be confirmed to exist in vivo [43,49]. In other biofluids other interaction partners could be more prevalent, for example in urine Tamm-Horsfall protein (THP; uromodulin) was shown to possibly bind miRNAs [80]. Since number of miRNAs in cell dramatically exceed number of AGO proteins (14 times) significant part of mature miRNAs can be bound with c RISC [81-83] and other proteins with classic RNA-binding motifs like HuR, AUF1, etc. [79], involved in transport and functioning of miRNA [84,85].

High density and, to a lesser extent, low density lipoproteins (HDL and LDL, respectively) are another type of confirmed miRNAs transporters in blood, carrying distinct populations of miRNA [38-40]. HDL and LDL are 5 to $1000 \mathrm{~nm}$ supramolecular complexes (nano- or microparticles) composed of lipoproteins and an assorted collection of lipids [86,87]. Despite the high concentrations of HDL and LDL, it is estimated that they contain no more than $10 \%$ of cf-miRNA detectable in blood plasma [39]. 
Substantial part of cf-miRNA in blood, urine and other biological fluids are packed in membrane-coated extracellular vesicles (EV) which are secreted by normal and cancer cells [88-92]. EV is a collective term describing 30-1000 $\mathrm{nm}$ particles coated by a double membrane layer, including exosomes, microvesicles and apoptotic bodies which differ in size, structure, surface markers, molecular composition including distinct miRNAs subsets (Table 2) $[15,20,21,93]$. On average, one milliliter of blood and urine contains $10^{8}-10^{12}$ or $3-8 \times 10^{9}$ exosomes, correspondingly $[94,95]$. Some reports suggest that exosomes can be the main miRNA transporters in blood and saliva [31]. Exosomes derived from $4 \mathrm{~mL}$ of blood serum typically yield approximately $2-10 \mathrm{ng}$ of RNA; exosomes derived from $10 \mathrm{~mL}$ urine yield approximately 2-4 ng RNA, while whole blood serum and urine contain about 10-fold more RNA [94]. Thus, a substantial fraction of cf-miRNA must be associated with proteins, complexes and vesicles other than exosomes. Stoichiometric analysis has shown that the miRNA content of exosomes is not as high as previously thought, with no more than a copy of any single miRNA per exosome, in average [96]. It should be noted that most of miR-16 and miR-223, packed in exosomes, were found to be in complexes with AGO2, adding more fuel to the debate of the dominant form of miRNA circulation in blood [97].

Molecular pattern of apoptotic bodies is not so characteristic like exosomes [16] and can include a variety of proteins, fragments of genomic DNA, most types of RNA including mature and immature miRNA $[15,98]$. Thus, analyzing miRNA isolated from apoptotic bodies special care should be put into managing potential background. Frequently EV isolation is the first step in the cf-miRNA investigation studies. The methods used for EV enrichment are worth a separate for discussion and have been well summarized in a number of reviews [99-101].

As it was mentioned before EV contains membrane and thus a set of lipids like phosphatidylserine, cholesterol, ceramide and sphinogolipids in exosomes [102,103] and lysphosphatidylcholines, sphingmyelin and acylcarnitines in microvesicules $[93,104,105]$. Presence of lipids in EV suggests necessity of their elimination during miRNA isolation process as well as previously mentioned disintegration of miRNA complexes with biomolecules.

Additionally, recent data suggests that a subpopulation of cf-miRNA circulates bound to the surface blood cells (Table 2). This miRNA fraction is perspective as a source of diagnostic markers because the expression of some cell surface bonded miRNAs changes with the development of cancer [27,32].

To date, there is no universally accepted hypothesis on generation of free cf-miRNA pool. Some types of miRNA-bearing complexes could be actively secreted (exosomes) [106], while for others passive leakage from damaged or dying cells is more feasible $[107,108]$. Another unknown is how, presumably, different clearance rates of different complexes could impact the half-life of different populations of cf-miRNA.

\section{Handling and Storage of Biological Fluids before miRNA Isolation}

A key step in cf-miRNA isolation includes separation of the liquid portion of biofluids from cells and cell debris. This is necessary to prevent the contamination of sample by cell miRNAs. More than half (almost $58 \%$ ) of diagnostically relevant miRNAs are highly expressed in at least one type of blood cell [109]. Hemolysis results in significant increase in levels of many cf-miRNAs, including, most prominently, the eritrocyte-specific miR-451a [109-112]. Significant number of epithelial cells is present in urine, saliva, cerebrospinal and other biofluids [113-115] and should be removed before they have the chance to contribute to the cf-miRNA by active secretion or passive leakage. That is commonly achieved by sequential centrifugation at low and high speed $[19,116,117]$ with subsequent separation of cell and debris-free supernatants.

Storage conditions of biofluids samples before removal of cell debris and subsequent storage of blood plasma/serum, cell-free urine and other fluids affect the efficacy of cf-miRNA isolation and quantification [118,119]. Use samples preserved in the slurry resin [119], long-term storage may decrease miRNA concentration in the sample as do 
multiple freeze-thaw cycles [4,118]. As described in the review [4] for midterm storage ( $<20$ month) no major differences in serum miRNA levels were observed between $-80{ }^{\circ} \mathrm{C}$ and $-20^{\circ} \mathrm{C}$, nonetheless some individual miRNA were seriously affected by those conditions. However, a slightly decrease within the range of 2-4 years; after 6 years of storage, a significant decrease of miRNA levels was perceived that only accentuates in the course of time.

Concerning dried serum spots incomplete drying of blots before storing was prejudicial for its preservation [4].

In experiments with urine all conditions demonstrated a surprising degree of stability of miRNAs: by the end of ten freeze-thaw cycles, $23-37 \%$ of the initial amount remained; over the 5-day period of storage at room temperature, $35 \%$ of the initial amount remained; and at $4{ }^{\circ} \mathrm{C}, 42-56 \%$ of the initial amount remained [120].

With that, it is possible that different fractions of miRNA, including particle-free miRNA and EV cargo miRNA can differ in sensitivity to storage conditions. For example, exosomal miRNAs showed extra stability under different storage conditions [121]. Stability of individual miRNA in general also depends on the storage conditions. For example, miR-145 and miR-20a degraded at room temperature, but both are stable at $4{ }^{\circ} \mathrm{C},-20{ }^{\circ} \mathrm{C}$ and $-80^{\circ} \mathrm{C}$ for $72 \mathrm{~h}$ in serum and as cDNA, which was additionally shown to be stable for at least 3 months at $-20{ }^{\circ} \mathrm{C}$ and survive four freeze-thaw cycles at $-20{ }^{\circ} \mathrm{C}$ without significant degradation [122].

Based on the foregoing, it may be concluded that not all biofluids are similar in terms of storage conditions and the method and time of storage should be determined by the tasks set in each specific case.

\section{4. miRNA Isolation from Biofluids}

\subsection{General Considerations and Technical Parameters Defining Isolation Method}

While choosing a method for isolation of miRNAs from biological fluids, it is necessary to take into account the peculiarities of their composition (ionics, proteins, polysaccharides, etc.), which can affect the efficiency of this isolation. For example, blood plasma contains high amount of proteins with total concentration of $7.2 \mathrm{~g} / \mathrm{dL}$ forhealthyadult human [123]. Accordingly, the concentration of chaotropic agents should be sufficient to extract miRNAs from various protein complexes. Urine contains a large fraction of nitrogen, with urea the most predominant, phosphorus, sodium and potassium, with the total suspended solids at $21 \mathrm{mg} / \mathrm{L}$ and total dissolved solids at $31.4 \mathrm{mg} / \mathrm{g}$ [124]. That is why, while using chaotropic salts (guanidine), their concentration should be lower than for isolation of miRNA from blood plasma. Normal saliva contains a large amount of glucose (0.5-1.00 mg/100 mL) [125], which can also affect the efficiency of excretion.

Progress in cf-miRNA extraction technologies has made it evident that any effective protocol should successfully achieve three main goals:

- enable complete dissociation of miRNA complexes with biomolecules of different nature;

- protect miRNA from enzymatic and non-enzymatic degradation during isolation regardless of their sequence;

- prevent contamination of miRNA preparations with inhibitors of enzymes used in downstream analyses or substances that hinder accurate quantification by UV absorption or fluorescence detection.

While numerous protocols allow for total RNA isolation, several more recent options are specifically tailored for miRNA isolation and provide either isolation of total RNA without loss of miRNA or selective purification of miRNA [70]. The choice of isolation method not only determines the quality and quantity of extracted miRNA as a whole, but can also favor isolation of certain individual cf-miRNAs leading to differences in the expression of the same miRNAs when isolated by different methods. Extraction of at least some cf-miRNAs is closely dependent on the extraction method suggesting incomplete dissociation of cf-miRNA complexes and highlighting a connection between the efficacy of isolation, miRNA sequence and type of complexing with biomolecules [126]. 
For example, depending on the starting volume of the biological samples used, the conditions of the protocol can favor the extraction of GC-poor miRNAs [127]. Such differences in isolation efficiency can have a dramatic impact on downstream analyses and most importantly normalization of cf-miRNAs.

Successful liberation of miRNA from complexes is the key to efficient miRNA isolation. Formation of complexes with proteins and lipoproteins can be sequence dependent. Complexes of different type can have different affinities and stabilized by different types of interactions (ionic, hydrophobic, etc.). EV contain membrane featuring distinct combinations of lipids: phosphatidylserine, cholesterol, ceramide and sphinogolipids in exosomes [102,103]; lysphosphatidylcholines, sphingmyelin and acylcarnitines in microvesicles $[93,104,105]$. High lipid content of EV and lipoproteins needs to be removed during miRNA isolation and any possible interaction with miRNA should be disrupted.

Complete dissociation of heterogeneous complexes in the presence of high abundance of biomolecules of varied nature often demands using high excess of denaturing solutions. This is true for blood plasma, serum and especially urine. To ensure adequate denaturation and removal of the high protein content from samples (albumin, immunoglobulins, coagulation and complement components among others), the lysis reagent-to-specimen ratio has to be increased several-fold. Together with the starting fluid volume, this is the most variable step in different protocols [128] leads to use large volume of pelleting reagents or increasing of efficacy of miRNA binding by adsorbents.

When planning a miRNA study, it is necessary to choose an extraction method taking into account the following parameters: sample type, expected type of miRNA packaging and its abundance, compatibility of the method with downstream applications (for example, with the method of EVs isolation), the duration and cost of the procedure, the available infrastructure (e.g., ability to safely handle and dispose of hazardous substances.

\subsection{Methods of miRNA Isolation from Biofliuds}

The overwhelming majority of currently used methods for miRNAs isolation from biological fluids are based on acid guanidinium thiocyanate-phenol-chloroform extraction, pioneered by Chomczynski and Sacchi in 1987 [129,130]. This method allows efficient fractionation of RNA, DNA and proteins and dissociates most part of miRNA complexes, which is why it is considered the "gold standard" for total RNA (and by proxy miRNA) extraction. A number of commercial kits, for example, Trizol LS, utilize phenol-based extraction for isolation of miRNAs in a fast and simplified manner and can also further specialize in dealing with specific sample types, such as serum and plasma, animal or plant tissue [70]. Products like miRVANA and miRNeasy include an additional stage of purification on columns with fiberglass sorbents for miRNA enrichment [131]. Solid phase extraction methods take advantage of the interactions between the functional groups of nucleic acids and solid sorbents under particular conditions. The adsorption of nucleic acids on the silica surface can be regulated with the use of chaotropic agents at different $\mathrm{pH}$, temperature or ionic strength and additionally enhanced by the addition of bivalent metal ions into the sorption buffer or the sorbent itself [132]. The efficiency of elution also depends on $\mathrm{pH}$ and temperature, although recently RNAse-free water is the elution buffer of choice, given its convenience for most downstream applications.

A number of comparative analyses show that methods based on guanidinium thiocyanate-phenol-chloroform extraction are superior in terms of the efficiency, but different versions of the protocol differ in performance (Table 3) [133]. 
Table 3. Comparative studies of different miRNA isolation methods.

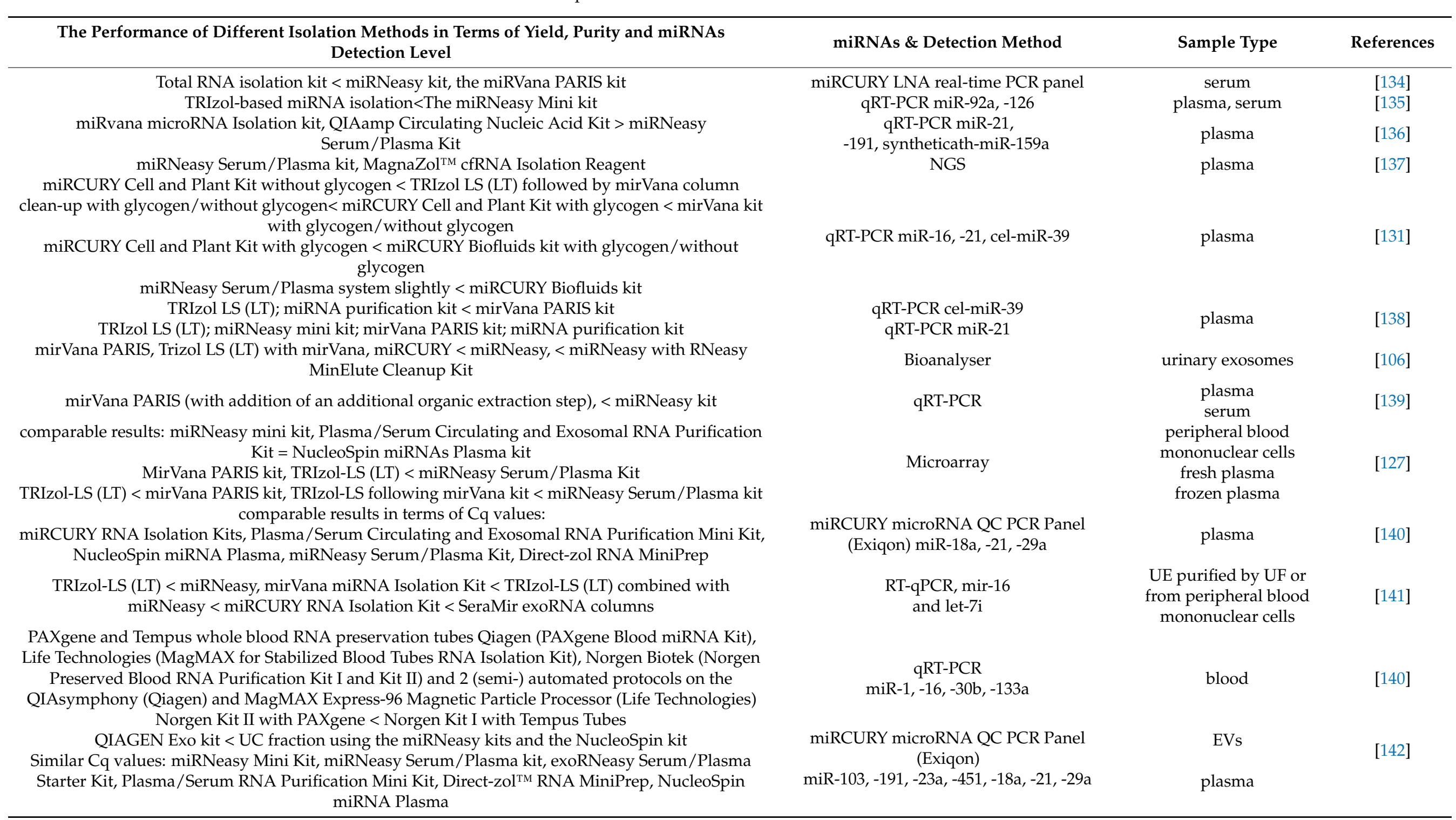


Table 3. Cont.

The Performance of Different Isolation Methods in Terms of Yield, Purity and miRNAs Detection Level

\section{miRNeasy slightly better than miRCURY} miRCUR $<$ miRNeasy

miRCURY biofluids $=$ miRNeasy kits miRCURY $<$ miRNeasy

miRNeasy Serum/Plasma kit, Plasma/Serum Circulating RNA Purification Kit $<$ miRCURY RNA Isolation Kit-Biofluids; mirVana PARIS Kit; NucleoSpin miRNA Plasma

PureLink commercial column extraction kit $<$ TiO2 nanofibers

Phenol and column-based procedure and a column-based procedure, in the presence or absence of two RNA carriers (yeast RNA and MS2 RNA); others carriers and their absence $<$ yeast RNA

ExoRNeasy Serum/Plasma Starter Kit (Cat. 77023), Plasma/Serum RNA Purification Mini Kit, Direct-zol $^{\mathrm{TM}}$ RNA MiniPrep < miRNeasy kits (Mini and Serum/Plasma kits) and NucleoSpin kit

Trizol LS reagent isolation method $<$ miRNeasy mini kit by $35 \%$

Trizol LS < miRCURY < miRNeasy kit, with some peculiarities concerning different sample volumes

mirVana and the Plasma/Serum RNA Purification Mini $<$ miRNeasy Serum/Plasma $<$ miRCURY Biofluids and the miRNeasy Advanced Serum/Plasma

exoRNeasy Serum/Plasma Exosome slightly <Ultracentrifugation + miRNeasy kit

Circulating Nucleic Acid Kit < TRIzol LS (TF); miRNEasy; RNA extraction kit and the MiRCURY RNA Isolation Kit-intermediate

miRNeasy Serum/Plasma kit (Qiagen, Germany), miRVANA miRNA Isolation Kit (Ambion, Austin TX, USA) and TRIzol LS (TF) < Urine microRNA purification kit

Quick-cfRNA Serum and plasma; Isolate II miRNA kit; PureLink RNA mini kit; Monarch total RNA miniprep kit $<$ miRNeasy Serum/Plasma Advanced kit $<$ miRNeasy

\section{miRNAs \& Detection Method}

RT-qPCR, mir-16, -106a, -222, -223

RT-qPCR, mir-30c-2-3p, -106a, -204, -222,

TaqMan miRNA PCR system (Applied Biosystems, California, USA), miRCURY

LNA microRNA PCR system (Exiqon) and miScript miRNA PCR system (Qiagen),

$$
\text { miR-16, -141, -135a }
$$

qRT-PCR miR-21, -191, spiked cel-miR-54

NGS

Bioanalyzer,

qRT-PCR

miR-122, -21-1, -30d, -451a

qRT-PCR RNU6, miR-145, -20a

NGS, qRT-PCR miR-106a, -222, -16, -223

NGS, qRT-PCR let-7a-5p, miR-150-5p,

$-16-5 p,-122-5 p,-21-5 p,-191-5 p$, cel-miR-39-3p

NGS

qRT-qPCR miR-16, -10a-5p, -196a-5p) and exogenous cel-miR-39

qRT-PCR miR-19b, -92a, -93, -103, -144, $-345-3 p,-486,-494-3 p,-1306$

\section{Sample Type}

plasma exosomes

plasma

urinary exosome

plasma

MDA-MB-231 breast cancer cells

plasma

plasma

serum

plasma and circulating exosomes

plasma cf-miRNA

plasma EVmiRNA

plasma

CSF samples

ovine plasma, fresh and frozen

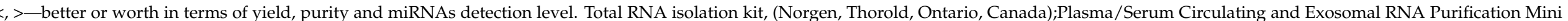

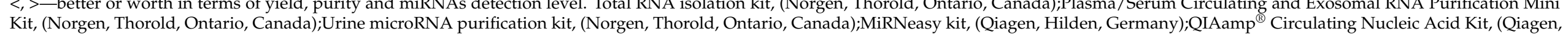

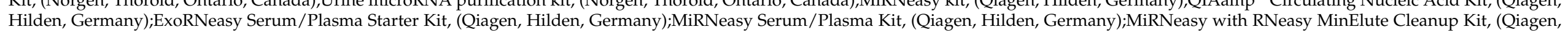

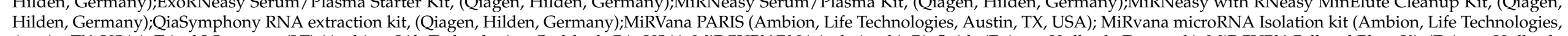

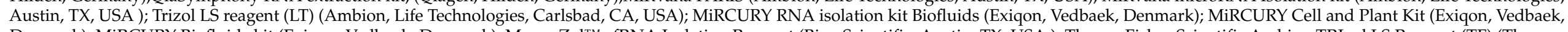

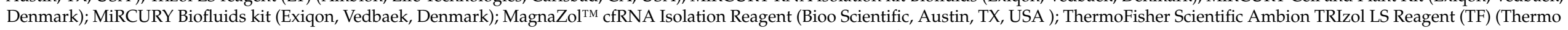

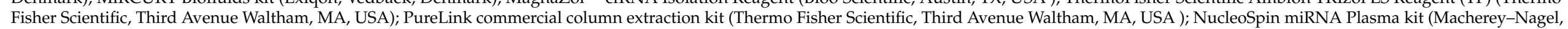

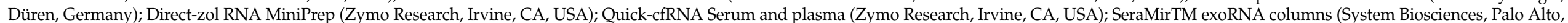
CA, USA); PureLink RNA mini kit (Bioline, Memphis, TN, USA); Monarch total RNA miniprep kit (NEB, Hitchin, UK). 
However, with all of the advantages, this method has some significant limitations. The procedure is time-consuming (40-60 $\mathrm{min}$ ) and poorly scalable to the starting volume of the sample, requires high quality reagents (phenol). In addition, phenol is highly toxic; thus, protective equipment (flow hood) and chemical waste management systems are required to minimize impact on personnel health and environment. The disadvantages of the method also include the partial loss of RNA with a low GC content [149]. All of the above mentioned creates difficulties for its routine use in many scenarios, including clinical setting [150].

To date, several strategies have been suggested as replacement for acid phenolchloroform extraction. Strong chaotropic properties of guanidinium thiocyanate allow efficient dissociation of both cell-free DNA and RNA complexes. However, some cf-miRNA complexes seem to resist the effects of guanidinium thiocyanate [151]. We previously suggested using Folch solution combined with guanidinium thiocyanate to disrupt hydrophobic interactions and assure complete dissociation of miRNA-containing complexes with subsequent application of the mix directly to fiberglass sorbents [151]. The method avoids bypasses using phenol or detergents, which is undesirable due to micellation and subsequent reduction in the efficiency of fiberglass sorbent. The method was shown to successfully retrieve miRNA from blood plasma, but has proven cumbersome for cf-miRNA extraction from urine due to the large starting volume.

In the mercury LNA RT kit (Qiagen, Hilden, Germany) instead of a laborious organic extraction procedure, cf-miRNA complexes are dissociated and excess protein and lipoprotein content is precipitated while miRNA is purified from the supernatant using fiberglass columns [133]. Extraction only requires $30 \mathrm{~min}$ and avoids highly toxic chemical agents. According to several studies, this approach is at least as effective as phenol-chloroform extraction [131,152]. Possible drawbacks of the methods could include partial loss of miRNA as a result of incomplete denaturation of the complexes or co-precipitation with excess biopolymers present in biological fluids. There is also evidence that an additional phosphorylation step may be required to use the obtained preparations for miRNA sequencing analysis [131,152].

Another method based on precipitation of biopolymers with octanoic acid was offered for immunoglobulin isolation [153]. In our lab, we found that complexes of miRNA in blood and urine were dissociated and pelleted by octanoic acid in the presence guanidinium thiocyanate, followed miRNA cleanup with fiberglass columns [154]. The method has demonstrated good efficacy of miRNA isolation from blood and even better performance in isolating urine cf-miRNA. Meanwhile, disadvantages of the method have not been fully explored yet.

Some isolation techniques are to be used when special downstream analyses are planned. For example, the most commonly used method to study protein/RNA complexes is co-immunoprecipitation of RNA with antibodies against the protein interacting with it [155]. Immunoprecipitation can be conducted when antibodies are added to solution and then mixed with the antibody sorbent in the resulting mixture, or an antibody is immobilized to a sorbent and then added to a solution of the protein. These approaches allow to study miRNA-AGO2 complexes [48]. It is known that immunoprecipitation which differ in the order of interaction of the components of the complex, (antigen (Ago2) antibodies and PA-sepharose) as well as in presence of blocking antibodies favor different miRNAs [48]. The authors suggest that non-specific binding to PA-sepharose and autoantibodies against miRNA binding proteins might contribute obtained results [48].

Lipoprotein-bound miRNAs can be isolated using sequential density ultracentrifugation of plasma with the adjustment to well-defined densities using potassium bromide salt. Another method used to separate plasma lipoproteins is the size exclusion chromatography, often with a fast-protein liquid chromatography (FPLC) system combined with columns filled with high-resolution stationary phases [156]. Affinity chromatography using columns linked to monoclonal antibodies specific to apolipoproteins offer one more approach of plasma lipoprotein isolation. However, the use of low $\mathrm{pH}$ required to elute lipoproteins 
retained by the immuno-affinity column lead to potential risk for the loss of nucleic acids from the purified lipoprotein. Thus, sequential density ultracentrifugation remains the standard for the isolation of well-defined lipoprotein classes in sufficient quantities to conduct subsequent in vitro or in vivo studies of lipoprotein function and RNA composition [156].

Finally, there are methods and kits designed used for miRNA isolation from sources other than biofluids, which could be adopted for cf-miRNA. For example, RNAgem (microGEM, Southampton, UK) provides temperature-driven, single-tube extraction of total RNA and miRNA from mammalian cells, tissues, insects, bacteria and virus.

The presence or the absence of the precipitation of miRNA and the type of the coprecipitator may affect the miRNA yield during miRNA isolation. The re-precipitation stage represents an additional stage of miRNA sample processing which lead to longer time of isolation and to potential loss of miRNA. The similar problem is known for circulating DNA precipitation, for which in unpredictable DNA loss or contamination was shown for some precipitation protocols, especially those which used positively charged compounds [157]. RNA bacteriophage carrier (MS2), yeast RNA, tRNA and glycogen are usually used carriers $[137,158-160]$. The most common co-precipitator is glycogen; however, the combination of tRNA and glycogen was shown to improve the yield and purity of RNA greatly and to maximize the extraction of miRNA from plasma when using the TRIzol LS [160]. In our opinion, the most suitable carrier is glycogen, since it does not contain components of a nucleic nature which may interfere subsequent analysis of miRNAs (NGS, microchip technology, etc.).

Numerous efforts have been taken to compare the effectiveness of different miRNA isolation methods (Table 3). Most of these studies compare protocols for miRNA isolation from blood plasma and most commonly simple phenol-chloroform extraction is superior to both phenol extraction with column-based cleanup techniques and phenol-free column-based methods (Table 3). No conclusive results have been obtained regarding the differences in the performance of column-based methods, suggesting that an even greater effort is still needed to compare existing extraction methods and working toward developing universal standards for miRNA extraction (Table 3; [116]).

Rapidly developing microfluidic technologies could further enhance cf-miRNA extraction. Microfluidic devices are compact units composed of a network of microchannels with diameters of tens to hundreds of micrometers capable of handling viscous media within a concentration range of pico- to microliters. Specialized units are used for tuning of fluid movement. Microfluidic devices have a tremendous potential and are able to reproduce laboratory techniques on a microscale with a high accuracy and specificity [161]. MiRNA isolation as well as their detection is among areas of application of microfluidic technologies. Recently developed microfluidic platforms can perform effective exosome separation and exosomal miRNA detection for liquid biopsies within a single device. Such methods offer advantages of integrity and fast procedure [162]. Moreover, in microscale processes reagent consumption can be reduced from milliliters to microliters. [161].

\section{Conclusions}

Current data clearly show there is no single most effective method of cf-miRNAs isolation and the choice of methodology is often dictated by sample type and properties of the miRNA fraction under investigation, as well as the ease of use in the context of each specific research project. This strongly aligns with the opinion of NIH Extracellular RNA Communication Consortium, which states that, despite the significant development of the methodology, there is no optimal method for isolating miRNAs and work on the development and optimization of new approaches to this problem must be continued [152]. At this point, both attempts to refine and optimize existing technologies and exploration of novel approaches could shift this paradigm and give a significant boost to cf-miRNA studies and potentially see some of their diagnostic applications make an appearance in the clinical setting. 
Author Contributions: O.B. and M.K. performed data analysis, manuscript preparation; I.Z. contributed to manuscript editing; A.Y. contributed to data analysis; P.L. performed supervising and manuscript editing. All authors have read and agreed to the published version of the manuscript.

Funding: The research was carried out within the state assignment of Ministry of Health of Russian Federation (\#121031300227-2 “Use of extracellular microRNA for non-invasive diagnostics of lung cancer") and the Russian state budget project to the ICBFM SB RAS (\#121030200173-6 “Diagnostics and therapy of oncological diseases").

Institutional Review Board Statement: Not applicable.

Informed Consent Statement: Not applicable.

Acknowledgments: We would like to express our gratitude to Faina Solov'eva for the help with Figure 1 visualization.

Conflicts of Interest: The authors declare no conflict of interest.

\section{References}

1. Montani, F.; Bianchi, F. Circulating Cancer Biomarkers: The Macro-revolution of the Micro-RNA. EBioMedicine 2016, 5, 4-6. [CrossRef] [PubMed]

2. Sohel, M.M.H. Extracellular/Circulating MicroRNAs: Release Mechanisms, Functions and Challenges. Achiev. Life Sci. 2016, 10, 175-186. [CrossRef]

3. Zhao, C.; Sun, X.; Li, L. Biogenesis and function of extracellular miRNAs. ExRNA 2019, 1, 38. [CrossRef]

4. Silva, S.; Lopes, C.; Teixeira, A.; Carneiro de Sousa, M.; Medeiros, R. Forensic miRNA: Potential biomarker for body fluids? Forensic. Sci. Int. Genet. 2015, 14, 1-10. [CrossRef]

5. Ha, M.; Kim, V. Regulation of microRNA biogenesis. Nat. Rev. Mol. Cell Biol. 2014, 15, 509-524. [CrossRef] [PubMed]

6. Chiang, H.; Schoenfeld, L.; Ruby, J.; Auyeung, V.; Spies, N.; Baek, D.; Johnston, W.; Russ, C.; Luo, S.; Babiarz, J.; et al. Mammalian microRNAs: Experimental evaluation of novel and previously annotated genes. Genes Dev. 2010, 24, 992-1009. [CrossRef]

7. Heale, B.; Keegan, L.; O'Connell, M. The Effect of RNA Editing and ADARs on miRNA Biogenesis and Function. Adv. Exp. Med. Biol. 2010, 700, 76-84. [CrossRef] [PubMed]

8. Zhang, X.Q.; Yang, J.H. Decoding the Atlas of RNA Modifications from Epitranscriptome Sequencing Data. Methods Mol. Biol. 2019, 1870, 107-124. [CrossRef] [PubMed]

9. Tusup, M.; Kundig, T.; Pascolo, S. Epitranscriptomics of cancer. World J. Clin. Oncol. 2018, 9, 42-55. [CrossRef] [PubMed]

10. Chen, K.; Zhao, B.S.; He, C. Nucleic Acid Modifications in Regulation of Gene Expression. Cell Chem. Biol. 2016, 23, 74-85. [CrossRef]

11. Xie, W.; Sowemimo, I.; Hayashi, R.; Wang, J.; Burkard, T.; Brennecke, J.; Ameres, S.; Patel, D. Structure-function analysis of microRNA 3'-end trimming by Nibbler. Proc. Natl. Acad. Sci. USA 2020, 117, 30370-30379. [CrossRef] [PubMed]

12. Liang, H.; Jiao, Z.; Rong, W.; Qu, S.; Liao, Z.; Sun, X.; Wei, Y.; Zhao, Q.; Wang, J.; Liu, Y.; et al. 3'-Terminal 2'-O-methylation of lung cancer miR-21-5p enhances its stability and association with Argonaute 2. Nucleic Acids Res. 2020, 48, 7027-7040. [CrossRef] [PubMed]

13. Trixl, L.; Lusser, A. The dynamic RNA modification 5-methylcytosine and its emerging role as an epitranscriptomic mark. Wiley Interdiscip. Rev. RNA 2019, 10, e1510. [CrossRef]

14. van der Kwast, R.V.C.T.; van Ingen, E.; Parma, L.; Peters, H.A.B.; Quax, P.H.A.; Nossent, A. Adenosine-to-Inosine Editing of MicroRNA-487b Alters Target Gene Selection After Ischemia and Promotes Neovascularization. Circ. Res. 2018, 122, 444-456. [CrossRef] [PubMed]

15. Crescitelli, R.; Lässer, C.; Szabó, T.; Kittel, A.; Eldh, M.; Dianzani, I.; Buzás, E.; Lötvall, J. Distinct RNA profiles in subpopulations of extracellular vesicles: Apoptotic bodies, microvesicles and exosomes. J. Extracell. Vesicles 2013, 2. [CrossRef]

16. Zernecke, A.; Bidzhekov, K.; Noels, H.; Shagdarsuren, E.; Gan, L.; Denecke, B.; Hristov, M.; Köppel, T.; Jahantigh, M.; Lutgens, E.; et al. Delivery of microRNA-126 by apoptotic bodies induces CXCL12-dependent vascular protection. Sci. Signal. 2009, 2. [CrossRef]

17. Karin-Kujundzic, V.; Sola, I.; Predavec, N.; Potkonjak, A.; Somen, E.; Mioc, P.; Serman, A.; Vranic, S.; Serman, L. Novel Epigenetic Biomarkers in Pregnancy-Related Disorders and Cancers. Cells 2019, 8, 1459. [CrossRef]

18. Bryzgunova, O.; Zaripov, M.; Skvortsova, T.; Lekchnov, E.; Grigor'eva, A.; Morozkin, E.; Zaporozhchenko, I.; Morozkin, E.; Ryabchikova, E.; Yurchenko, Y.; et al. Comparative Study of Extracellular Vesicles from the Urine of Healthy Individuals and Prostate Cancer Patients. PLoS ONE 2016, 11, e0157566. [CrossRef] [PubMed]

19. Konoshenko, M.; Lekchnov, E.; Bryzgunova, O.; Zaporozhchenko, I.; Yarmoschuk, S.; Pashkovskaya, O.; Pak, S.; Laktionov, P. The Panel of 12 Cell-Free MicroRNAs as Potential Biomarkers in Prostate Neoplasms. Diagnostics 2020, 10, 38. [CrossRef] [PubMed]

20. Hunter, M.; Ismail, N.; Zhang, X.; Aguda, B.; Lee, E.; Yu, L.; Xiao, T.; Schafer, J.; Lee, M.; Schmittgen, T.; et al. Detection of microRNA expression in human peripheral blood microvesicles. PLoS ONE 2008, 3, e3694. [CrossRef] [PubMed] 
21. Colombo, M.; Raposo, G.; Théry, C. Biogenesis, Secretion, and Intercellular Interactions of Exosomes and Other Extracellular Vesicles. Annu. Rev. Cell Dev. Biol. 2014, 30, 255-289. [CrossRef]

22. Qian, Z.; Shen, Q.; Yang, X.; Qiu, Y.; Zhang, W. The Role of Extracellular Vesicles: An Epigenetic View of the Cancer Microenvironment. BioMed Res. Int. 2015, 2015, 649161. [CrossRef] [PubMed]

23. Florijn, B.; Duijs, J.M.G.J.; Levels, J.H.; Dallinga-Thie, G.; Wang, Y.; Boing, A.; Yuana, Y.; Stam, W.; Limpens, R.W.A.L.; Au, Y.; et al. Diabetic Nephropathy Alters the Distribution of Circulating Angiogenic MicroRNAs Among Extracellular Vesicles, HDL, and Ago-2. Diabetes 2019, 68, 2287-2300. [CrossRef] [PubMed]

24. Meldolesi, J. Extracellular vesicles, news about their role in immune cells: Physiology, pathology and diseases. Clin. Exp. Immunol. 2019, 196, 318-327. [CrossRef] [PubMed]

25. Morello, M.; Minciacchi, V.; de Candia, P.; Yang, J.; Posadas, E.; Kim, H.; Griffiths, D.; Bhowmick, N.; Chung, L.; Gandellini, P.; et al. Large oncosomes mediate intercellular transfer of functional microRNA. Cell Cycle 2013, 12, 3526-3536. [CrossRef] [PubMed]

26. Choi, D.; Lee, T.; Spinelli, C.; Chennakrishnaiah, S.; D'Asti, E.; Rak, J. Extracellular vesicle communication pathways as regulatory targets of oncogenic transformation. Semin. Cell Dev. Biol. 2017, 67, 11-22. [CrossRef]

27. Konoshenko, M.; Sagaradze, G.; Orlova, E.; Shtam, T.; Proskura, K.; Kamyshinsky, R.; Yunusova, N.; Alexandrova, A.; Efimenko, A.; Tamkovich, S. Total Blood Exosomes in Breast Cancer: Potential Role in Crucial Steps of Tumorigenesis. Int. J. Mol. Sci. 2020, 21, 7341. [CrossRef]

28. Grigor'eva, A.; Dyrkheeva, N.; Bryzgunova, O.; Tamkovich, S.; Chelobanov, B.; Ryabchikova, E. Contamination of exosome preparations, isolated from biological fluids. Biochem. Suppl. Ser. B Biomed. Chem. 2017, 11, 265-271. [CrossRef]

29. Valadi, H.; Ekström, K.; Bossios, A.; Sjöstrand, M.; Lee, J.; Lötvall, J. Exosome-mediated transfer of mRNAs and microRNAs is a novel mechanism of genetic exchange between cells. Nat. Cell Biol. 2007, 9, 654-659. [CrossRef]

30. Mitchell, P.; Parkin, R.; Kroh, E.; Fritz, B.; Wyman, S.; Pogosova-Agadjanyan, E.; Peterson, A.; Noteboom, J.; O’Briant, K.; Allen, A.; et al. Circulating microRNAs as stable blood-based markers for cancer detection. Proc. Natl. Acad. Sci. USA 2008, 105, 10513-10518. [CrossRef]

31. Gallo, A.; Tandon, M.; Alevizos, I.; Illei, G. The majority of microRNAs detectable in serum and saliva is concentrated in exosomes. PLoS ONE 2012, 7, e30679. [CrossRef]

32. Tamkovich, S.; Tutanov, O.; Efimenko, A.; Grigor'eva, A.; Ryabchikova, E.; Kirushina, N.; Vlassov, V.; Tkachuk, V.; Laktionov, P. Blood Circulating Exosomes Contain Distinguishable Fractions of Free and Cell-Surface-Associated Vesicles. Curr. Mol. Med. 2019, 19, 273-285. [CrossRef] [PubMed]

33. Xu, R.; Rai, A.; Chen, M.; Suwakulsiri, W.; Greening, D.; Simpson, R. Extracellular vesicles in cancer-Implications for future improvements in cancer care. Nat. Rev. Clin. Oncol. 2018, 15, 617-638. [CrossRef] [PubMed]

34. Zijlstra, C.; Stoorvogel, W. Prostasomes as a source of diagnostic biomarkers for prostate cancer. J. Clin. Investig. 2016, 126, 1144-1151. [CrossRef]

35. Serre, C.; Busuttil, V.; Botto, J. Intrinsic and extrinsic regulation of human skin melanogenesis and pigmentation. Int. J. Cosmet. Sci. 2018, 40, 328-347. [CrossRef]

36. Mannavola, F.; D’Oronzo, S.; Cives, M.; Stucci, L.; Ranieri, G.; Silvestris, F.; Tucci, M. Extracellular Vesicles and Epigenetic Modifications Are Hallmarks of Melanoma Progression. Int. J. Mol. Sci. 2019, 21, 52. [CrossRef]

37. Edelstein, L. The role of platelet microvesicles in intercellular communication. Platelets 2017, 28, 222-227. [CrossRef]

38. Vickers, K.; Palmisano, B.; Shoucri, B.; Shamburek, R.; Remaley, A. MicroRNAs are transported in plasma and delivered to recipient cells by high-density lipoproteins. Nat. Cell Biol. 2011, 13, 423-433. [CrossRef]

39. Wagner, J.; Riwanto, M.; Besler, C.; Knau, A.; Fichtlscherer, S.; Röxe, T.; Zeiher, A.; Landmesser, U.; Dimmeler, S. Characterization of levels and cellular transfer of circulating lipoprotein-bound microRNAs. Arterioscler. Thromb. Vasc. Biol. 2013, 33, 1392-1400. [CrossRef] [PubMed]

40. Niculescu, L.; Simionescu, N.; Sanda, G.; Carnuta, M.; Stancu, C.; Popescu, A.; Popescu, M.; Vlad, A.; Dimulescu, D.; Simionescu, M.; et al. MiR-486 and miR-92a identified in circulating HDL discriminate between stable and vulnerable coronary artery disease patients. PLoS ONE 2015, 10, e0140958. [CrossRef] [PubMed]

41. Sedgeman, L.; Beysen, C.; Ramirez Solano, M.; Michell, D.; Sheng, Q.; Zhao, S.; Turner, S.; Linton, M.; Vickers, K. Beta cell secretion of miR-375 to HDL is inversely associated with insulin secretion. Sci. Rep. 2019, 9, 3803. [CrossRef] [PubMed]

42. Michell, D.; Vickers, K. Lipoprotein carriers of microRNAs. Biochim. Biophys. Acta 2016, 1861, 2069-2074. [CrossRef]

43. Turchinovich, A.; Weiz, L.; Langheinz, A.; Burwinkel, B. Characterization of extracellular circulating microRNA. Nucleic Acids Res. 2011, 39, 7223-7233. [CrossRef]

44. Arroyo, J.; Chevillet, J.; Kroh, E.; Ruf, I.; Pritchard, C.; Gibson, D.; Mitchell, P.; Bennett, C.; Pogosova-Agadjanyan, E.; Stirewalt, D.; et al. Argonaute2 complexes carry a population of circulating microRNAs independent of vesicles in human plasma. Proc. Natl. Acad. Sci. USA 2011, 108, 5003-5008. [CrossRef] [PubMed]

45. Turchinovich, A.; Burwinkel, B. Distinct AGO1 and AGO2 associated miRNA profiles in human cells and blood plasma. RNA Biol. 2012, 9, 1066-1075. [CrossRef] [PubMed]

46. Martino, F.; Lorenzen, J.; Schmidt, J.; Schmidt, M.; Broll, M.; Görzig, Y.; Kielstein, J.; Thum, T. Circulating microRNAs are not eliminated by hemodialysis. PLoS ONE 2012, 7, e38269. [CrossRef] 
47. Geekiyanage, H.; Rayatpisheh, S.; Wohlschlegel, J.; Brown, R.; Ambros, V. Extracellular microRNAs in human circulation are associated with miRISC complexes that are accessible to anti-AGO2 antibody and can bind target mimic oligonucleotides. Proc. Natl. Acad. Sci. USA 2020, 117, 24213-24223. [CrossRef]

48. Panshin, D.; Kondratov, K. The Efficiency of Immunoprecipitation of microRNA/Ago2 Complexes from Human Blood Plasma Is Protocol Dependent. Mol. Biol. 2020, 54, 213-219. [CrossRef]

49. Wang, K.; Zhang, S.; Weber, J.; Baxter, D.; Galas, D. Export of microRNAs and microRNA-protective protein by mammalian cells. Nucleic Acids Res. 2010, 38, 7248-7259. [CrossRef]

50. Zhang, Q.; Higginbotham, J.; Jeppesen, D.; Yang, Y.; Li, W.; McKinley, E.; Graves-Deal, R.; Ping, J.; Britain, C.; Dorsett, K.; et al. Transfer of Functional Cargo in Exomeres. Cell Rep. 2019, 27, 940-954. [CrossRef] [PubMed]

51. Bairamukov, V.; Bukatin, A.; Landa, S.; Burdakov, V.; Shtam, T.; Chelnokova, I.; Fedorova, N.; Filatov, M.; Starodubtseva, M. Biomechanical Properties of Blood Plasma Extracellular Vesicles Revealed by Atomic Force Microscopy. Biology 2020, 10, 4. [CrossRef] [PubMed]

52. Bosson, A.; Zamudio, J.; Sharp, P. Endogenous miRNA and target concentrations determine susceptibility to potential ceRNA competition. Mol. Cell 2014, 56, 347-359. [CrossRef]

53. Guo, L.; Chen, F. A challenge for miRNA: Multiple isomiRs in miRNAomics. Gene 2014, 544, 1-7. [CrossRef]

54. Li, S.C.; Tsai, K.W.; Pan, H.W.; Jeng, Y.M.; Ho, M.R.; Li, W.H. MicroRNA 3' end nucleotide modification patterns and arm selection preference in liver tissues. BMC Syst. Biol. 2012, 6 (Suppl. 2), S14. [CrossRef]

55. Kim, B.; Jeong, K.; Kim, V. Genome-wide Mapping of DROSHA Cleavage Sites on Primary MicroRNAs and Noncanonical Substrates. Mol. Cell 2017, 66, 258-269. [CrossRef] [PubMed]

56. Liu, X.; Zheng, Q.; Vrettos, N.; Maragkakis, M.; Alexiou, P.; Gregory, B.; Mourelatos, Z. A MicroRNA precursor surveillance system in quality control of MicroRNA synthesis. Mol. Cell 2014, 55, 868-879. [CrossRef]

57. Wulff, B.E.; Nishikura, K. Modulation of microRNA expression and function by ADARs. Curr. Top. Microbiol. Immunol. 2012, 353, 91-109. [CrossRef] [PubMed]

58. Morin, R.; O'Connor, M.; Griffith, M.; Kuchenbauer, F.; Delaney, A.; Prabhu, A.; Zhao, Y.; McDonald, H.; Zeng, T.; Hirst, M.; et al. Application of massively parallel sequencing to microRNA profiling and discovery in human embryonic stem cells. Genome Res. 2008, 18, 610-621. [CrossRef]

59. Lee, L.; Zhang, S.; Etheridge, A.; Ma, L.; Martin, D.; Galas, D.; Wang, K. Complexity of the microRNA repertoire revealed by next-generation sequencing. RNA 2010, 16, 2170-2180. [CrossRef]

60. Torsin, L.; Petrescu, G.E.D.; Sabo, A.; Chen, B.; Brehar, F.; Dragomir, M.; Calin, G. Editing and Chemical Modifications on Non-Coding RNAs in Cancer: A New Tale with Clinical Significance. Int. J. Mol. Sci. 2021, 22, e581. [CrossRef]

61. Tsui, N.B.Y.; Ng, E.K.O.; Lo, Y.M.M.D. Stability of endogenous and added RNA in blood specimens, serum, and plasma. Clin. Chem. Clin. Chem. 2002, 48, 1647-1653. [CrossRef]

62. Danilevich, V.; Sorokin, V.; Moiseev, Y.; Sizova, S. Preparation and Properties of Nanoparticles, tRNA-Bivalent Metal Cation (Me2+) Complexes, and Prospects of Their Practical Use. Dokl. Biochem. Biophys. 2018, 479, 118-122. [CrossRef]

63. Etheridge, A.; Gomes, C.; Pereira, R.; Galas, D.; Wang, K. The complexity, function and applications of RNA in circulation. Front. Genet. 2013, 4, 115. [CrossRef] [PubMed]

64. Houck, J.; Berman, L. Serum Ribonuclease Activity. J. Appl. Physiol. 1958, 12, 473-476. [CrossRef] [PubMed]

65. Reddi, K.; Holland, J. Elevated serum ribonuclease in patients with pancreatic cancer. Proc. Natl. Acad. Sci. USA 1976, 73, 2308-2310. [CrossRef] [PubMed]

66. Koczera, P.; Martin, L.; Marx, G.; Schuerholz, T. The Ribonuclease A Superfamily in Humans: Canonical RNases as the Buttress of Innate Immunity. Int. J. Mol. Sci. 2016, 17, 1278. [CrossRef]

67. Hynle, I.; Meuffels, M.; Poznanski, W. Determination of Phosphodiesterase I Activity in Human Blood Serum. Clin. Chem. 1975, 2110, 1383-1387.

68. Lüthje, J.; Ogilvie, A. 5'-Nucleotide phosphodiesterase isoenzymes in human serum: Quantitative measurement and some biochemical properties. Clin. Chim. Acta 1987, 164, 275-284. [CrossRef]

69. Bryzgunova, O.; Laktionov, P. Extracellular Nucleic Acids in Urine: Sources, Structure, Diagnostic Potential. Acta Naturae 2015, 7 , 48-54. [CrossRef] [PubMed]

70. Wright, K.; de Silva, K.; Purdie, A.; Plain, K. Comparison of methods for miRNA isolation and quantification from ovine plasma. Sci. Rep. 2020, 10, 1-11. [CrossRef]

71. Fleischhacker, M.; Schmidt, B. Circulating nucleic acids (CNAs) and cancer-a survey. Biochim. Biophys. Acta 2007, 1775, 181-232. [CrossRef] [PubMed]

72. Weber, J.; Baxter, D.; Zhang, S.; Huang, D.; Huang, K.; Lee, M.; Galas, D.; Wang, K. The microRNA spectrum in 12 body fluids. Clin. Chem. 2010, 56, 1733-1741. [CrossRef] [PubMed]

73. Sohel, M.M.H. Circulating microRNAs as biomarkers in cancer diagnosis. Life Sci. 2020, 248, 117473. [CrossRef] [PubMed]

74. O'Brien, J.; Hayder, H.; Zayed, Y.; Peng, C. Overview of MicroRNA Biogenesis, Mechanisms of Actions, and Circulation. Front. Endocrinol. 2018, 9, 402. [CrossRef] [PubMed]

75. Beltrami, C.; Clayton, A.; Newbury, L.; Corish, P.; Jenkins, R.; Phillips, A.; Fraser, D.; Bowen, T. Stabilization of urinary microRNAs by association with exosomes and Argonaute 2 protein. Noncoding RNA 2015, 1, 151-166. [CrossRef] [PubMed] 
76. Beltrami, C.; Besnier, M.; Shantikumar, S.; Shearn, A.; Rajakaruna, C.; Laftah, A.; Sessa, F.; Spinetti, G.; Petretto, E.; Angelini, G.; et al. Human pericardial fluid contains exosomes enriched with cardiovascular-expressed microRNAs and promotes therapeutic angiogenesis. Mol. Ther. 2017, 25, 679-693. [CrossRef]

77. Tan, G.; Garchow, B.; Liu, X.; Yeung, J.; Morris, J.-P., 4th; Cuellar, T.; McManus, M.; Kiriakidou, M. Expanded RNA-binding activities of mammalian Argonaute 2. Nucleic Acids Res. 2009, 37, 7533-7545. [CrossRef] [PubMed]

78. Lima, W.; Wu, H.; Nichols, J.; Sun, H.; Murray, H.; Crooke, S. Binding and cleavage specificities of human Argonaute2. J. Biol. Chem. 2009, 284, 26017-26028. [CrossRef]

79. Zealy, R.; Wrenn, S.; Davila, S.; Min, K.-W.; Yoon, J.-H. MicroRNA-binding proteins: Specificity and function. Wiley Interdiscip. Rev. RNA 2017, 8, e1414. [CrossRef]

80. Wachalska, M.; Koppers-Lalic, D.; van Eijndhoven, M.; Pegtel, M.; Geldof, A.; Lipinska, A.; van Moorselaar, R.; Bijnsdorp, I. Protein Complexes in Urine Interfere with Extracellular Vesicle Biomarker Studies. J. Circ. Biomark. 2016, 1, 4. [CrossRef]

81. Janas, M.; Wang, B.; Harris, A.; Aguiar, M.; Shaffer, J.; Subrahmanyam, Y.; Behlke, M.; Wucherpfennig, K.; Gygi, S.; Gagnon, E.; et al. Alternative RISC assembly: Binding and repression of microRNA-mRNA duplexes by human Ago proteins. RNA 2012, 18, 2041-2055. [CrossRef] [PubMed]

82. Stalder, L.; Heusermann, W.; Sokol, L.; Trojer, D.; Wirz, J.; Hean, J.; Fritzsche, A.; Aeschimann, F.; Pfanzagl, V.; Basselet, P.; et al. The rough endoplasmatic reticulum is a central nucleation site of siRNA-mediated RNA silencing. EMBO J. 2013, 32, 1115-1127. [CrossRef]

83. Flores, O.; Kennedy, E.; Skalsky, R.; Cullen, B. Differential RISC association of endogenous human microRNAs predicts their inhibitory potential. Nucleic Acids Res. 2014, 42, 4629-4639. [CrossRef] [PubMed]

84. Mukherjee, K.; Ghoshal, B.; Ghosh, S.; Chakrabarty, Y.; Shwetha, S.; Das, S.; Bhattacharyya, S. Reversible HuR-microRNA binding controls extracellular export of miR-122 and augments stress response. EMBO Rep. 2016, 17, 1184-1203. [CrossRef] [PubMed]

85. Yoon, J.; Jo, M.; White, E.; De, S.; Hafner, M.; Zucconi, B.; Abdelmohsen, K.; Martindale, J.; Yang, X.; Wood, W.-H. 3rd.; et al. AUF1 promotes let-7b loading on Argonaute 2. Genes Dev. 2015, 29, 1599-1604. [CrossRef] [PubMed]

86. Skipski, V.; Barclay, M.; Barclay, R.; Fetzer, V.; Good, J.; Archibald, F. Lipid composition of human serum lipoproteins. Biochem. J. 1967, 104, 340-352. [CrossRef]

87. Kontush, A.; Lindahl, M.; Lhomme, M.; Calabresi, L.; Chapman, M.; Davidson, W. Structure of HDL: Particle subclasses and molecular components. In Handbook of Experimental Pharmacology; Springer: Cham, Switzerland, 2015; Volume 224, pp. 3-51. [CrossRef]

88. Yu, S.; Cao, H.; Shen, B.; Feng, J. Tumor-derived exosomes in cancer progression and treatment failure. Oncotarget 2015, 6, 37151-37168. [CrossRef]

89. Caby, M.; Lankar, D.; Vincendeau-Scherrer, C.; Raposo, G.; Bonnerot, C. Exosomal-like vesicles are present in human blood plasma. Int. Immunol. 2005, 17, 879-887. [CrossRef]

90. Vella, L.; Sharples, R.; Lawson, V.; Masters, C.; Cappai, R.; Hill, A. Packaging of prions into exosomes is associated with a novel pathway of PrP processing. J. Pathol. 2007, 211, 582-590. [CrossRef]

91. Tamkovich, S.; Grigor'eva, A.; Eremina, A.; Tupikin, A.; Kabilov, M.; Chernykh, V.; Vlassov, V.; Ryabchikova, E. What information can be obtained from the tears of a patient with primary open angle glaucoma? Clin. Chim. Acta 2019, 495, 529-537. [CrossRef]

92. Pisitkun, T.; Shen, R.; Knepper, M. Identification and proteomic profiling of exosomes in human urine. Proc. Natl. Acad. Sci. USA 2004, 101, 13368-13373. [CrossRef] [PubMed]

93. Sedgwick, A.; D'Souza-Schorey, C. The biology of extracellular microvesicles. Traffic 2018, 19, 319-327. [CrossRef] [PubMed]

94. Li, M.; Zeringer, E.; Barta, T.; Schageman, J.; Cheng, A.; Vlassov, A. Analysis of the RNA content of the exosomes derived from blood serum and urine and its potential as biomarkers. Philos. Trans. R Soc. Lond. B Biol. Sci. 2014, 369, 20130502. [CrossRef]

95. Fernando, M.; Jiang, C.; Krzyzanowski, G.; Ryan, W. New evidence that a large proportion of human blood plasma cell-free DNA is localized in exosomes. PLoS ONE 2017, 12, e0183915. [CrossRef]

96. Tosar, J.; Cayota, A. Detection and analysis of non-vesicular extracellular RNA. Methods Mol. Biol. 2018, 1740, 125-137. [CrossRef]

97. Li, L.; Zhu, D.; Huang, L.; Zhang, J.; Bian, Z.; Chen, X.; Liu, Y.; Zhang, C.-Y.; Zen, K. Argonaute 2 Complexes Selectively Protect the Circulating MicroRNAs in Cell-Secreted Microvesicles. PLoS ONE 2012, 7, 1-9. [CrossRef]

98. Muhsin-Sharafaldine, M.; McLellan, A. Tumor-Derived Apoptotic Vesicles: With Death They Do Part. Front. Immunol. 2018, 9 , 957. [CrossRef] [PubMed]

99. Konoshenko, M.; Lekchnov, E.; Vlassov, A.; Laktionov, P. Isolation of Extracellular Vesicles: General Methodologies and Latest Trends. BioMed Res. Int. 2018, 2018, 8545347. [CrossRef]

100. Zhang, P.; Yeo, J.; Lim, C. Advances in Technologies for Purification and Enrichment of Extracellular Vesicles. SLAS Technol. 2019, 24, 477-488. [CrossRef]

101. Momen-Heravi, F.; Balaj, L.; Alian, S.; Mantel, P.; Halleck, A.; Trachtenberg, A.; Soria, C.; Oquin, S.; Bonebreak, C.; Saracoglu, E.; et al. Current methods for the isolation of extracellular vesicles. Biol. Chem. 2013, 394, 1253-1262. [CrossRef]

102. Van Niel, G.; D'Angelo, G.; Raposo, G. Shedding light on the cell biology of extracellular vesicles. Nat. Rev. Mol. Cell Biol. 2018, 19, 213-228. [CrossRef]

103. Record, M.; Carayon, K.; Poirot, M.; Silvente-Poirot, S. Exosomes as new vesicular lipid transporters involved in cell-cell communication and various pathophysiologies. Biochim. Biophys. Acta 2014, 1841, 108-120. [CrossRef] [PubMed] 
104. Frey, B.; Gaipl, U. The immune functions of phosphatidylserine in membranes of dying cells and microvesicles. Semin. Immunopathol. 2011, 33, 497-516. [CrossRef]

105. Kastelowitz, N.; Yin, H. Exosomes and Microvesicles: Identification and Targeting By Particle Size and Lipid Chemical Probes. ChemBioChem 2014, 15, 923-928. [CrossRef]

106. Channavajjhala, S.; Rossato, M.; Morandini, F.; Castagna, A.; Pizzolo, F.; Bazzoni, F.; Olivieri, O. Optimizing the purification and analysis of miRNAs from urinary exosomes. Clin. Chem. Lab. Med. 2014, 52, 345-354. [CrossRef] [PubMed]

107. Turchinovich, A.; Tonevitsky, A.; Cho, W.; Burwinkel, B. Check and mate to exosomal extracellular miRNA: New lesson from a new approach. Front. Mol. Biosci. 2015, 2, 11. [CrossRef]

108. Rahat, B.; Ali, T.; Sapehia, D.; Mahajan, A.; Kaur, J. Circulating Cell-Free Nucleic Acids as Epigenetic Biomarkers in Precision Medicine. Front. Genet. 2020, 11, 844. [CrossRef]

109. Pritchard, C.; Kroh, E.; Wood, B.; Arroyo, J.; Dougherty, K.; Miyaji, M.; Tait, J.; Tewari, M. Blood cell origin of circulating microRNAs: A cautionary note for cancer biomarker studies. Cancer Prev. Res. 2012, 5, 492-497. [CrossRef]

110. Landoni, E.; Miceli, R.; Callari, M.; Tiberio, P.; Appierto, V.; Angeloni, V.; Mariani, L.; Daidone, M. Proposal of supervised data analysis strategy of plasma miRNAs from hybridisation array data with an application to assess hemolysis-related deregulation. BMC Bioinform. 2015, 16, 388. [CrossRef]

111. Kirschner, M.; Edelman, J.; Kao, S.; Vallely, M.; van Zandwijk, N.; Reid, G. The Impact of Hemolysis on Cell-Free microRNA Biomarkers. Front. Genet. 2013, 4, 94. [CrossRef] [PubMed]

112. Blondal, T.; Nielsen, S.; Baker, A.; Andreasen, D.; Mouritzen, P.; Teilum, M.; Dahlsveen, I. Assessing sample and miRNA profile quality in serum and plasma or other biofluids. Methods 2013, 59, S1-S6. [CrossRef] [PubMed]

113. Skoberne, A.; Konieczny, A.; Schiffer, M. Glomerular epithelial cells in the urine: What has to be done to make them worthwhile? Am. J. Physiol. Renal. Physiol. 2009, 296, F230-F241. [CrossRef] [PubMed]

114. Theda, C.; Hwang, S.; Czajko, A.; Loke, Y.; Leong, P.; Craig, J. Quantitation of the cellular content of saliva and buccal swab samples. Sci. Rep. 2018, 8, 6944. [CrossRef] [PubMed]

115. Torzewski, M.; Lackner, K.; Bohl, J.; Sommer, C. The Common Cell Types of Cerebrospinal Fluid. In Book Integrated Cytology of Cerebrospinal Fluid; Springer: Berlin/Heidelberg, Germany, 2008; pp. 9-22. [CrossRef]

116. Tiberio, P.; Callari, M.; Angeloni, V.; Daidone, M.; Appierto, V. Challenges in using circulating miRNAs as cancer biomarkers. BioMed Res. Int. 2015, 2015, 731479. [CrossRef]

117. Cheng, H.; Yi, H.; Kim, Y.; Kroh, E.; Chien, J.; Eaton, K.; Goodman, M.; Tait, J.; Tewari, M.; Pritchard, C. Plasma processing conditions substantially influence circulating microRNA biomarker levels. PLoS ONE 2013, 8, e64795. [CrossRef]

118. Becker, N.; Lockwood, C. Pre-analytical variables in miRNA analysis. Clin. Biochem. 2013, 46, 861-868. [CrossRef]

119. Martínez-Fernández, M.; Paramio, J.; Dueñas, M. RNA Detection in Urine: From RNA Extraction to Good Normalizer Molecules. J. Mol. Diagn. 2016, 18, 15-22. [CrossRef]

120. Mall, C.; Rocke, D.; Durbin-Johnson, B.; Weiss, R. Stability of miRNA in human urine supports its biomarker potential. Biomark. Med. 2013, 7, 623-631. [CrossRef]

121. Ge, Q.; Zhou, Y.; Lu, J.; Bai, Y.; Xie, X.; Lu, Z. MiRNA in plasma exosome is stable under different storage conditions. Molecules 2014, 19, 1568-1575. [CrossRef]

122. Trakunram, K.; Champoochana, N.; Chaniad, P.; Thongsuksai, P.; Raungrut, P. MicroRNA Isolation by Trizol-Based Method and Its Stability in Stored Serum and cDNA Derivatives. Asian Pac. J. Cancer Prev. 2019, 20, 1641-1647. [CrossRef]

123. Blanco, A.; Blanco, G. Proteins. Blood plasma proteins. In Medical Biochemistry; Elsevier: Amsterdam, The Netherlands, 2017; Chapter 3; pp. 21-71. [CrossRef]

124. Rose, C.; Parker, A.; Jefferson, B.; Cartmell, E. The Characterization of Feces and Urine: A Review of the Literature to Inform Advanced Treatment Technology. Crit. Rev. Environ. Sci. Technol. 2015, 45, 1827-1879. [CrossRef]

125. Gupta, S.; Nayak, M.; Sunitha, J.; Dawar, G.; Sinha, N.; Rallan, N. Correlation of salivary glucose level with blood glucose level in diabetes mellitus. J. Oral Maxillofac. Pathol. 2017, 21, 334-339. [CrossRef]

126. Zhang, N.; Hu, G.; Myers, T.G.; Williamson, P.R. Protocols for the Analysis of microRNA Expression, Biogenesis, and Function in Immune Cells. Curr. Protoc. Immunol. 2019, 126, e78. [CrossRef] [PubMed]

127. Monleau, M.; Bonnel, S.; Gostan, T.; Blanchard, D.; Courgnaud, V.; Lecellier, C. Comparison of different extraction techniques to profile microRNAs from human sera and peripheral blood mononuclear cells. BMC Genom. 2014, 15, 395. [CrossRef]

128. Moldovan, L.; Batte, K.; Trgovcich, J.; Wisler, J.; Marsh, C.; Piper, M. Methodological challenges in utilizing miRNAs as circulating biomarkers. J. Cell Mol. Med. 2014, 18, 371-390. [CrossRef] [PubMed]

129. Chomczynski, P.; Sacchi, N. Single-step method of RNA isolation by acid guanidinium thiocyanate-phenol-chloroform extraction. Anal. Biochem. 1987, 162, 156-159. [CrossRef]

130. Chomczynski, P.; Sacchi, N. The single-step method of RNA isolation by acid guanidinium thiocyanate-phenol-chloroform extraction: Twenty-something years on. Nat. Protoc. 2006, 1, 581-585. [CrossRef]

131. McAlexander, M.; Phillips, M.; Witwer, K. Comparison of Methods for miRNA Extraction from Plasma and Quantitative Recovery of RNA from Cerebrospinal Fluid. Front. Genet. 2013, 4, 83. [CrossRef]

132. Hu, W.-P.; Chen, Y.-C.; Chen, W.-Y. Improve sample preparation process for miRNA isolation from the culture cells by using silica fiber membrane. Sci. Rep. 2020, 10, 21132. [CrossRef] 
133. El-Khoury, V.; Pierson, S.; Kaoma, T.; Bernardin, F.; Berchem, G. Assessing cellular and circulating miRNA recovery: The impact of the RNA isolation method and the quantity of input material. Sci. Rep. 2016, 6, 1-14. [CrossRef]

134. Kroh, E.; Parkin, R.; Mitchell, P.; Tewari, M. Analysis of circulating microRNA biomarkers in plasma and serum using quantitative reverse transcription-PCR (qRT-PCR). Methods 2010, 50, 298-301. [CrossRef]

135. Fichtlscherer, S.; De Rosa, S.; Fox, H.; Schwietz, T.; Fischer, A.; Liebetrau, C.; Weber, M.; Hamm, C.; Röxe, T.; Müller-Ardogan, M.; et al. Circulating microRNAs in patients with coronary artery disease. Circ. Res. 2010, 107, 677-684. [CrossRef] [PubMed]

136. Page, K.; Guttery, D.; Zahra, N.; Primrose, L.; Elshaw, S.; Pringle, J.; Blighe, K.; Marchese, S.; Hills, A.; Woodley, L.; et al. Influence of plasma processing on recovery and analysis of circulating nucleic acids. PLoS ONE 2013, 8, e77963. [CrossRef]

137. Moret, I.; Sánchez-Izquierdo, D.; Iborra, M.; Tortosa, L.; Navarro-Puche, A.; Nos, P.; Cervera, J.; Beltrán, B. Assessing an improved protocol for plasma microRNA extraction. PLoS ONE 2013, 8, e82753. [CrossRef] [PubMed]

138. Sourvinou, I.; Markou, A.; Lianidou, E. Quantification of circulating miRNAs in plasma: Effect of preanalytical and analytical parameters on their isolation and stability. J. Mol. Diagn. 2013, 15, 827-834. [CrossRef] [PubMed]

139. Häntzsch, M.; Tolios, A.; Beutner, F.; Nagel, D.; Thiery, J.; Teupser, D.; Holdt, L. Comparison of whole blood RNA preservation tubes and novel generation RNA extraction kits for analysis of mRNA and MiRNA profiles. PLoS ONE 2014, 9, e113298. [CrossRef] [PubMed]

140. Brunet-Vega, A.; Pericay, C.; Quílez, M.; Ramírez-Lázaro, M.; Calvet, X.; Lario, S. Variability in microRNA recovery from plasma: Comparison of five commercial kits. Anal. Biochem. 2015, 488, 28-35. [CrossRef]

141. Tan, G.; Khoo, A.; Tan, L. Evaluation of extraction kits and RT-qPCR systems adapted to high-throughput platform for circulating miRNAs. Sci. Rep. 2015, 5, 9430. [CrossRef] [PubMed]

142. Meerson, A.; Ploug, T. Assessment of six commercial plasma small RNA isolation kits using qRT-PCR and electrophoretic separation: Higher recovery of microRNA following ultracentrifugation. Biol. Methods Protoc. 2016, 1. [CrossRef] [PubMed]

143. Guo, Y.; Vickers, K.; Xiong, Y.; Zhao, S.; Sheng, Q.; Zhang, P.; Zhou, W.; Flynn, C. Comprehensive evaluation of extracellular small RNA isolation methods from serum in high throughput sequencing. BMC Genom. 2017, 18, 50. [CrossRef]

144. Ramón-Núñez, L.; Martos, L.; Fernández-Pardo, Á.; Oto, J.; Medina, P.; España, F.; Navarro, S. Comparison of protocols and RNA carriers for plasma miRNA isolation. Unraveling RNA carrier influence on miRNA isolation. PLoS ONE 2017, 12, e0187005. [CrossRef] [PubMed]

145. Jimenez, L.; Gionet-Gonzales, M.; Sedano, S.; Carballo, J.; Mendez, Y.; Zhong, W. Extraction of microRNAs from biological matrices with titanium dioxide nanofibers. Anal. Bioanal. Chem. 2018, 410, 1053-1060. [CrossRef] [PubMed]

146. Wong, R.-K.-Y.; MacMahon, M.; Woodside, J.; Simpson, D. A comparison of RNA extraction and sequencing protocols for detection of small RNAs in plasma. BMC Genom. 2019, 20, 1-12. [CrossRef] [PubMed]

147. Kloten, V.; Neumann, M.-H.-D.; Di Pasquale, F.; Sprenger-Haussels, M.; Shaffer, J.; Schlumpberger, M.; Herdean, A.; Betsou, F.; Ammerlaan, W.; Af Hällström, T.; et al. Multicenter evaluation of circulating plasma microRNA extraction technologies for the development of clinically feasible reverse transcription quantitative PCR and next-generation sequencing analytical work flows. Clin. Chem. 2019, 65, 1132-1140. [CrossRef] [PubMed]

148. Srinivasan, S.; Yeri, A.; Cheah, P.; Chung, A.; Danielson, K.; De Hoff, P.; Filant, J.; Laurent, C.; Laurent, L.; Magee, R.; et al. Small RNA sequencing across diverse biofluids identifies optimal methods for exRNA isolation. Cell 2019, 177, 446-462. [CrossRef]

149. Kim, Y.-K.; Yeo, J.; Kim, B.; Ha, M.; Kim, V.-N. Short structured RNAs with low GC content are selectively lost during extraction from a small number of cells. Mol. Cell. 2012, 46, 893-895. [CrossRef]

150. Vlassov, V.; Rykova, E.; Ponomaryova, A.; Zaporozhchenko, I.; Morozkin, E.; Cherdyntseva, N.; Laktionov, P. Circulating microRNAs in lung cancer: Prospects for diagnosis, prognosis, and prediction of antitumor treatment efficacy. Mol. Biol. 2015, 49, 48-57. [CrossRef]

151. Zaporozhchenko, I.; Morozkin, E.; Skvortsova, T.; Bryzgunova, O.; Bondar, A.; Loseva, E.; Vlassov, V.; Laktionov, P. A phenol-free method for isolation of microRNA from biological fluids. Anal. Biochem. 2015, 479, 43-47. [CrossRef]

152. Laurent, L.; Abdel-Mageed, A.; Adelson, P.; Arango, J.; Balaj, L.; Breakefield, X.; Carlson, E.; Carter, B.; Majem, B.; Chen, C.; et al. Meeting report: Discussions and preliminary findings on extracellular RNA measurement methods from laboratories in the NIH Extracellular RNA Communication Consortium. J. Extracell. Vesicles 2015, 4, 26533. [CrossRef]

153. Morais, V.; Berasain, P.; Massaldi, H. Immunoglobulin purification by caprylic acid. Methods Mol. Biol. 2014, 1129, 137-143. [CrossRef]

154. Lekchnov, E.; Zaporozhchenko, I.; Morozkin, E.; Bryzgunova, O.; Vlassov, V.; Laktionov, P. Protocol for miRNA isolation from biofluids. Anal. Biochem. 2016, 499, 78-84. [CrossRef]

155. Turchinovich, A.; Weiz, L.; Burwinkel, B. Isolation of circulating microRNA associated with RNA-binding protein. Methods Mol. Biol. 2013, 1024, 97-107. [CrossRef] [PubMed]

156. Li, K.; Wong, D.; Luk, F.; Kim, R.; Raffai, R. Isolation of Plasma Lipoproteins as a Source of Extracellular RNA. Methods Mol. Biol. 2018, 1740, 139-153. [CrossRef] [PubMed]

157. Bryzgunova, O.; Bondar, A.; Morozkin, E.; Mileyko, V.; Vlassov, V.; Laktionov, P. A reliable method to concentrate circulating DNA. Anal. Biochem. 2011, 408, 354-356. [CrossRef] [PubMed]

158. Parker, V.; Cushen, B.; Gavriil, E.; Marshall, B.; Waite, S.; Pacey, A.; Heath, P. Comparison and optimisation of microRNA extraction from the plasma of healthy pregnant women. Mol. Med. Rep. 2021, 23. [CrossRef] 
159. Rice, J.; Roberts, H.; Burton, J.; Pan, J.; States, V.; Rai, S.; Galandiuk, S. Assay reproducibility in clinical studies of plasma miRNA. PLoS ONE 2015, 10, e0121948. [CrossRef]

160. Ban, E.; Chae, D.; Yoo, Y.; Song, E. An improvement of miRNA extraction efficiency in human plasma. Anal. Bioanal. Chem. 2017, 409, 6397-6404. [CrossRef]

161. He, M.; Zeng, Y. Microfluidic Exosome Analysis toward Liquid Biopsy for Cancer. J. Lab. Autom. 2016, 21, 599-608. [CrossRef]

162. Salim, B.; Athira, M.; Kandaswamy, A.; Vijayakumar, M.; Saravanan, T.; Sairam, T. Microfluidic device for novel breast cancer screening by blood test using miRNA beacon probe. Biomed. Microdevices 2017, 19, 89. [CrossRef] 